\title{
FENOMENA FACEBOOK SEBAGAI MEDIA KOMUNIKASI BARU
}

\author{
Muhlis \\ Usman Jasad \\ Abdul Halik
}

\begin{abstract}
Abstrack: Tulisan ini akan mengurai tentang fenomena media sosial dalam hal ini facebook sebagai media komunikasi baru yang deskripsi fokusnya mencakup facebook, media komunikasi baru dan partisipasi pengguna facebook. Penelitian ini bersifat deskriptif kualitatif yakni menganalisis dan menggambarkan tentang realitas proses dakwah di media sosial. Lokasi penelitian ini adalah media sosial terkhusus facebook dengan objek penelitian yang akan diteliti meliputi aspek-aspek dakwah di media sosial yang terdiri dari dai dan bentuk dakwah. Pendekatan penelitian ini adalah studi fenomenologi dalam arti peneliti menghimpun data berkenaan dengan konsep, pendapat, pendirian, sikap, penilaian dan pemberian makna terhadap situasi atau pengalaman dalam kehidupan. Sumber data dalam penelitian ini adalah dai, facebooker dan aktif berdakwah di facebook sebagai sumber data primer yang diperoleh dengan cara observasi, wawancara, dan dokumentasi. Sedangkan data sekunder adalah data yang diperoleh dari berbagai literatur seperti buku, majalah, karya ilmiah yang relevan dengan penelitian. Instrumen utama dalam penelitian ini adalah peneliti sendiri dan jenis instrumen lain yang mencakup pedoman wawancara, pedoman observasi, dan alat dokumentasi. Teknik analisis data dalam penelitian ini adalah model interaktif Miles dan Huberman yakni analisis data dilakukan saat pengumpulan data berlangsung, dan setelah pengumpulan data dalam periode tertentu, ${ }^{1}$ sebagai berikut: a) Reduksi Data; b) Display atau Penyajian Data; dan c) Verifikasi atau kesimpulan

Fenomena yang sedang sangat digemari di era tahun 2000-an ini yaitu sebuah jejaring sosial facebook, dapat dikatakan sebagai sebuah revolusi cara berkomunikasi untuk mendapatkan teman. Dalam kehidupan normal seharihari selayaknya mendapatkan teman biasanya secara langsung tatap muka dan bisa akrab dengan teman juga secara tatap muka. Tetapi dengan jejaring sosial facebook, mendapatkan teman dan berbincang dengannya secara leluasa hanya sekali klik, maka semua deskripsi tentang teman baru bisa didapatkan.
\end{abstract}

\section{Keywords: Facebook, Komunikasi Baru}

\section{PENDAHULUAN}

Teknologi media informasi dan komunikasi berkembang pesat seiring dengan canggihnya industri media informasi dan komunikasi, baik itu cetak maupun elektronik yang menawarkan berita dan sensasi. Dengan derasnya arus informasi, manusia mengalami berbagai macam perubahan baik sosiokultural maupun struktural. Kondisi ini memungkinkan betapa pentingnya informasi dalam menanamkan pengetahuan pada peradaban manusia, agar tidak tertinggal dengan kemajuan zaman dan dapat memilah

\footnotetext{
${ }^{1}$ Sugiono, Metode Penelitian Kuantitatif, kualitatif dan R\&D, (Bandung: Alfabet, 2009), h.246
} 
informasi yang baik dan berguna. Untuk mendapatkan informasi dapat melalui bacaan atau mendengar berita, yang salah satunya bisa didapatkan dengan membeli majalah, surat kabar, tabloid dan sebagainya. Bagi sebagian masyarakat dengan membaca lebih memberikan keyakinan kepada dirinya karena ada proses intelektual dan intepretasi yang terjadi ketika membaca berita di media. ${ }^{2}$

Kemajuan teknologi telah menyebabkan perkembangan di berbagai aspek kehidupan. Di zaman yang serba digital sekarang ini, penggunaan internet, smartphone, media sosial sudah umum. Kehidupan yang dinamis menuntut setiap orang untuk dapat mengikuti perubahan agar tidak tertinggal dari yang lainnya. Ibarat koin yang bersisian kedinamisan kehidupan ini memiliki sisi positif dan negatifnya. Kemajuan teknologi komunikasi membawa kemudahan informasi bagi siapapun. Jika tidak digunakan secara tepat maka kemudahan ini bisa menjadi ancaman, khususnya para generasi muda. Internet merupakan salah satu dari kemajuan di bidang informasi, hanya dengan sekali klik maka informasi akan tersedia secara lengkap. Siapapun bisa mengaksesnya dengan mudah mulai dari anak-anak hingga orang tua. Apalagi dengan munculnya handphone pintar (smartphone), internetan jadi lebih mudah untuk diakses di mana saja dan kapan saja. Manfaatnya tentu tak diragukan lagi, bagi pelajar dan mahasiswa internet dijadikan salah satu sarana belajar dan mencari informasi dan tugas. Tak jarang pelajar menggunakan fasilitas internet ini untuk mengakses hal-hal yang sebenarnya dapat merusak moral.

Dakwah melalui internet juga bukanlah hal yang asing lagi, dengan membuat situs khusus yang berisi tentang ajaran-ajaran agama dan kebaikan. Di dalamnya bisa menjadi sarana tukar pikiran dan tanya jawab mengenai agama. Sasaran utama dakwah adalah para generasi muda yang cenderung rentan terbawa arus kehidupan. Dengan media internet anak muda yang mungkin enggan atau malu untuk bertanya mengenai agama bisa menggunakan situs ini untuk bertanya dan mengetahui informasi lebih dalam mengenai agama. ${ }^{3}$

Selain internet, media sosial bisa dijadikan lahan dakwah yang mungkin paling gampang dan efektif karena hampir setiap orang memiliki media sosial seperti facebook, twitter, instagram, Black Barry Massanger dan media sosial lainnya. Dengan media tersebut, dakwah yang disampaikan walau hanya satu baris bisa bermanfaat. Sekarang ini banyak pendakwah yang menyampaikan dakwahnya melalui media sosial yang tak hanya kalangan ustadz saja namun masyarakat luas pun bisa ikut berdakwah melalui media sosial ini. Hal ini agar dapat merubah trend generasi muda yang suka galau. Media sosial yang tadinya berfungsi untuk memberi kemudahan dalam mencari teman baru dan tetap berhubungan dengan teman lama telah berubah fungsi menjadi lahan bergalau ria karena seringnya status di media sosial berbau galau dan keluhan.

Terjadi pergeseran-pergeseran di tengah masyarakat yang tidak disadari akibat perubahan zaman. Seseorang yang berada di depan tak lagi menarik untuk diajak mengobrol, banyak orang sekarang lebih suka berjam-jam mengobrol atau chating di media sosial daripada dengan orang yang berada di sebelahnya yang mengakibatkan kurangnya interaksi secara nyata, dan ini sangat berbahaya karena membuat seseorang kurang peka terhadap lingkungan sekitarnya.

\footnotetext{
${ }^{3}$ Syarif Hidayatullah, Islam Virtual (keberadaan Dunia Islam di Internet) (Cet I Jakarta; Penerbit
}

${ }^{2}$ Ishadi, SK., Prospek Bisnis Informasi di Indonesia. (Cet. I Bandung; Pustaka Pelopor. 1999), h. Mifta. 2003). h. 63 
Dakwah adalah suatu proses mengajak, menyeru, dan membimbing umat manusia untuk berbuat baik dan mengikuti petunjuk Allah dan rasulNya. Usaha tersebut dilakukan dengan sengaja dan perencanaan matang baik dilakukan individu atau organisasi dengan sasaran umat perorangan atau sekelompok orang (masyarakat) agar mereka mengetahui, mengimani dan mengamalkan ajaran Islam dalam semua aspek kehidupan. Karena hal itu, maka dakwah bukanlah pekerjaan yang dipikirkan dan dikerjakan sambil lalu saja melainkan suatu pekerjaan yang telah diwajibkan bagi setiap pengikutnya $^{4}$

Dakwah dan teknologi adalah suatu yang tidak dapat dipisahkan. Hal ini jika berpijak pada konsep dakwah kontemporer yang mudah diterima oleh kalangan masa kini, teknologi bukan sesuatu yang dilarang. Meskipun di masa Rasulullah belum ditemukan adanya teknologi seperti yang berkembang pesat dewasa ini. Perkembangan dakwah perlu memperhatikan perkembangan teknologi, agar sesuatu yang dihadirkan mudah diterima, dan tidak ketinggalan zaman. Walaupun tidak semua teknologi informasi yang berkembang dewasa ini bersifat positif, ada kelebihan dan kekuranganya bagi kehidupan umat manusia. Dengan adanya teknologi informasi dapat dimanfaatkan sebagai media dakwah Islam. Kemajuan teknologi itu ibarat pisau bermata ganda, disatu sisi untuk memudahkan pekerjaan dan sisi lainnya bisa mencelakai orang lain. Karena memang kemajuan teknologi itu sangat tergantung pada dan di tangan siapa. Ketika berada di tangan orang yang baik maka baiklah manfaatnya, sebaliknya, ketika ia berada di tangan orang jahat maka jahatlah dampak yang dihasilkannya. Maka penggunanyalah yang menentukan ke arah mana ia gunakan, baik atau buruk tergantung di tangan penggunanya. Oleh karena itu sebagai juru dakwah dituntut piawai menggunakan dan memanfaatkan hasil kemajuan teknologi informasi, salah satunya melalui jejaring sosial facebook. ${ }^{5}$

Fenomena dakwah melalui jejaring sosial facebook khususnya di Indonesia mengalami perkembangan yang cukup pesat. Hal ini ditandai dengan hadirnya para aktivis dakwah untuk memanfaatkan facebook sebagai sarana media dakwah Islam. Semua pengguna facebook bisa melihat, belajar di facebook untuk menambah wawasan keilmuan dan informasi seputar dunia Islam. Facebook merupakan yang sangat tepat untuk dipakai sebagai strategi dakwah, bisa mengirim berbagai pesan dakwah melalui layanan tersebut. Dengan chatting melakukan strategi dakwah fardhiyah, sehingga pendekatan lebih intens dan ikatan persaudaraan akan semakin kuat. Yahoo messenger merupakan salah satu messenger yang dapat dipakai untuk berkomunikasi via media teks (chat) secara online. Yang memiliki banyak kegunaan di antaranya: chatting, telfon, webcam, mengirim file, mengirim gambar. Chatting bisa menggunakan fasilitas chatting untuk dakwah terutama dakwah fardiyah yaitu dakwah secara personal dengan seseorang dengan dakwah ini diharapkan sesorang mengetahui karakter sesorang serta mungkin bisa membantu menyelesaikan masalah-masalah yang dihadapinya. Conference pada fasilitas conference Yahoo massanger ini bisa membuat sebuah pengajian online, pesertannya diundang dari teman yang ada di computer. Dapat memberikan tausiyah secara lisan dan peserta mendengarkan ceramah yang diberikan melalui earphone/headphone. Bisa membuat sebuah ruangan yang temanya tentang kajian keIslaman di dalamnya adakan diskusi keIslaman serta tausiyah dengan bahasa yang menarik sehingga tidak membosankan.

\footnotetext{
${ }^{4}$ Moh. Ali Aziz, Ilmu Dakwah, Edisi Revisi, (Cet I, Jakarta: Kencana, 2004) h. 37

${ }^{5} \mathrm{http}$ //neysya-jatidiri.blogspot.com/2012/06/facebook-sebagai-media- dakwah.html di akses pada 1 maret 2015 jam 12.50 wib
} 
Tulisan ini akan mengurai tentang fenomena media sosial dalam hal ini facebook sebagai media komunikasi baru yang deskripsi fokusnya mencakup facebook, media komunikasi baru dan partisipasi pengguna facebook.

\section{KAJIAN TEORETIK}

\section{A. Dakwah dan Media Komunikasi Baru}

Islam adalah agama yang berisi dengan petunjuk-petunjuk agar manusia secara individual menjadi manusia yang baik, beradab, dan berkualitas, selalu berbuat baik sehingga mampu membangun sebuah peradaban yang maju, sebuah tatanan kehidupan yang manusiawi dalam arti kehidupan yang adil, maju bebas dari berbagai ancaman, penindasan, dan berbagai kekhawatiran. Agar mencapai yang diinginkan tersebut diperlukan apa yang dinamakan dengan dakwah. Karena dengan masuknya Islam dalam sejarah umat manusia, agama ini mencoba menyakinkan umat manusia tentang kebenarannya dan menyeru manusia agar menjadi penganutnya ${ }^{6}$.

Islam juga menganjurkan kearifan dalam memahami realitas masyarakat yang sifatnya ma'ruf, dan mencegah kemungkaran dengan memperhatikan keadaan dan kecenderungan manusia beserta sifat dan karakternya. Keadaan dan kecenderungan manusia secara individual maupun kolektif menjadi pertimbangan dasar bagi dakwah Islam sebagai proses yang saling mempengaruhi antarindividu, individu dengan kelompok, dan antarkelompok yang melibatkan aspek-aspek dinamika pemahaman dan kesadaran, penolakan dan penerimaan, kejumudan dan perubahan. Karena itu dakwah Islam sebagai proses saling mempengaruhi diimplementasikan secara arif (hikmah), terbuka, dialogis, dan manusiawi. Dakwah Islam dilakukan sebijaksana mungkin dengan memperhitungkan situasi dan kondisi objek dakwah, baik kemampun intelektual masyarakat maupun kondisi psikologi perkembangan mereka ${ }^{7}$.

Di samping itu "Islam" sebagai agama disebut agama dakwah, maksudnya adalah agama yang disebarluaskan dengan cara damai, tidak lewat kekerasan. Walaupun ada terjadi peperangan dalam sejarah Islam, baik di zaman Nabi Muhammad saw masih hidup atau di zaman sahabat dan sesudahnya, peperangan itu bukanlah dalam rangka menyebarkan atau mendakwahkan Islam, tetapi dalam rangka mempertahankan diri umat Islam atau melepaskan masyarakat dari penindasan penguasa tirani. Dalam Islam setiap peperangan yang dilakukan umat Islam untuk menyebarkan ajaran Islam. Dalam beberapa kasus peperangan yang dimenangkan oleh umat Islam di masa Nabi saw hidup, Nabi sendiri tidak pernah memaksa penduduk daerah yang ditundukkan atau orang dikalahkan untuk masuk Islam ${ }^{8}$.

Penjelasan di atas dapat dipahami bahwa sulit memisahkan dakwah dengan Islam karena Islam berkembang lewat dakwah. Karena pentingnya itulah, maka dakwah bukanlah pekerjaan yang dipikirkan dan dikerjakan sambil lalu saja melainkan suatu pekerjaan yang telah diwajibkan bagi setiap pengikutnya ${ }^{9}$

${ }^{6}$ Moh. Ali Aziz, Ilmu Dakwah, h. 1

${ }^{7}$ PP. Muhammadiyah, Dakwah Kultural Muhammadiyah, (Cet. II; Yogyakarta: PT. Surya Sarana Utama, 2005) hal.4-5

${ }^{8}$ Moh. Ali Aziz, Ilmu Dakwah, h. 1

${ }^{9}$ Moh. Ali Aziz, Ilmu Dakwah, h. 37 


\section{B. Media Komunikasi Baru}

Media baru itu sendiri merupakan konsep yang menjelaskan kemampuan media yang dengan dukungan perangkat digital dapat mengakses konten kapan saja, di mana saja sehingga memberikan kemampuan bagi siapa saja, baik sebagai penerima atau pengguna untuk berpartisipasi aktif, interaktif, dan kreatif terhadap umpan balik pesan yang pada gilirannya membentuk komunitas atau masyarakat baru melalui isi media. ${ }^{10}$ Lev Manovich yang ditulis oleh Alo Liliweri mendefenisikan media baru dalam delapan proposisi yaitu;

a. Media baru versus cyberculture, istilah media baru dan siberkultur sering dipakai secara bergantian. Media baru merupakan sebuah paradigma dan objek budaya (digital untuk televisi analog, iPhone), sedangkan siberkultur adalah beragam fenomena sosial yang berkaitan dengan jaringan komunikasi internet seperti blog, online multi-player game.

b. Media baru adalah media yang berbasis teknologi komputer sebagai platform distribusi informasi melalui situs Web, komputer multimedia, blu-ray disk, dll. Makna media baru bahkan kemudian harus direvisi seiring dengan kecepatan perubahan teknologi (sebagai objek budaya) pendukung media baru. Istilah media baru tidak akan baru lagi jika kebanyakan bentuk budaya akan didistribusikan melalui komputer.

c. Media baru merupakan media pertukaran data digital yang dikendalikan oleh software. Bahasa media baru didasarkan pada asumsi bahwa, semua benda budaya yang mengandalkan representasi digital mengirimkan informasi berbasis komputer demi peningkatan kualitas informasi itu sendiri. Seiring dengan perkembangan software komputer maka data-data digital akan semakin mudah dimanipulasi.

d. Media baru merupakan campuran antara konvensi budaya yang sudah ada dengan konvensi software. Kini media baru dapat dipahami sebagai campuran antara konvensi budaya yang lebih tua dan konvensi budaya baru dalam pengelolaan dan akses data yang semuanya diproses melalui manipulasi. Jadi kata "lama" dalam media lama sebagai lawan dari media baru menggambarkan kerja media atas data yang sekaligus merepresentasikan realitas visual dan pengalaman manusia, sedangkan kata "baru" menunjukkan bahwa data itu bersifat numerik. Sifat numerik itu ditunjang oleh komputer di mana pada komputer telah disediakan semacam tombol yang mengarahkan pengguna untuk memutuskan sesuatu secara jitu.

e. Media baru adalah media yang menghasilkan estetika baru, karena media baru menyediakan strategi untuk meningkatkan kualitas estetika konten (dapat memanipulasi foto dalam banyak versi dengan perangkat lunak Adobe Photoshop). Artinya media baru sangat bermanfaat untuk merekam momen penampilan realitas, dan sekaligus mengubah kualitas data dari rekaman tersebut.

f. Media baru sebagai pemercepat eksekusi algoritma, artinya segala algoritman yang sebelumnya dilakukan secara manual atau teknologi lain seperti kalkulator, maka kini eksekusi seperti itu harus berubah. Hadirnya komputer yang menyediakan perangkat lunak penghitungan maka orang dapat memperbesar kapasitas, mempercepat berbagai jenis perhitungan, karena itu komputer digital

${ }^{10}$ Alo Liliweri, Komunikasi Antar Personal. (Jakarta: Kencana, 2015) h. 284 
modern dapat dipandang sebagai kalkulator cepat yang dapat dikontrol secara sibernetik.

g. Media baru sebagai candra di muka yang dapat mengendalikan encoding informasi, media baru juga dipandang sebagai metamedia. Manovich malah mengatakan bahwa embrio media dimulai dikenal pada tahun 1920, maka media baru mulai berkembang cepat dalam jangka waktu yang tidak bisa diramalkan. Sementara itu metamedia merupakan media baru yang lahir bertepatan dengan postmodernisme.

h. Media baru juga dapat dipandang sebagai gagasan artikulasi paralel dari seni dan komputasi modern yang sejak akhir perang dunia II disebut seni kombinatorik. Seni ini merupakan proses penciptaan gambar yang sangat mirip dengan struktur spasial. Hal ini menggambarkan pula bahwa algoritma, ini bagian penting dari media baru, tidak tergantung pada teknologi, tetapi dapat dilaksanakan oleh manusia. $^{11}$

Karakteristik utama dari media baru yang membuatnya unik dan sangat berbeda dari media lama adalah representasi numerik, modularitas, otomatisasi, variabilitas, dan transcoding. Manovich hanya menfokuskan tiga aspek yaitu:

a. Variabilitas, merupakan salah satu karakteristik utama masyarakat postmodernisme, menjelaskan bahwa semua orang dapat memproduksi gambar dan suara menurut versi mereka. Variabilitas menjadi mungkin karena digitalisasi di mana semua informasi dikodekan dalam data biner 0 dan 1.

b. Modularity, satu konsep yang dipahami oleh masyarakat pascaindustri, menjelaskan bahwa media digital memiliki berbagai komponen bersifat diskrit artinya tampak terpisah namun setiap saat dapat disusun atau digabungkan dalam representasi data numerik, dari modularitas inilah orang dapat menciptakan variasi konten. Pendiskrit seperti menampilkan versi yang berbeda dari gambar atau suara yang sama.

c. Transcoding, merupakan proses memungkinkan para pengguna semakin mudah menerjemahkan apa yang dia kerjakan ke dalam format yang berbeda apalagi didukung oleh proses komputerisasi. Manovich mengemukakan bahwa media baru mempunyai dua lapisan yang berbeda, yaitu lapisan budaya dan lapisan komputer. $^{12}$

\section{Sejarah dan Perkembangan Facebook}

Asal mula Facebook berawal ketika Mark Zuckerberg (saat itu mahasiswa semester II Harvard University) membuat sebuah situs kontak jodoh untuk rekan rekan kampusnya. Zuckerberg yang terinspirasi dari situs Hot or Not dengan menamai situs buatannya Facemash.com. Metode situs ini yaitu menampilkan dua foto pasangan (pria dan wanita), di mana kedua pasangan ini akan dipilih oleh para anggota situs mana pasangan yang paling hot. Untuk menampilkan foto-foto pasangan di situs ini, Zuckerberg berupaya dengan segala cara mencari foto-foto rekannya dengan cara keliling door-to-door untuk meminta foto.

Zuckerberg membobol akses jaringan komputer kampusnya untuk mendapatkan foto-foto tambahan. Namun aksi ini diketahui pihak kampus dan mereka selanjutnya memblokir situs Facemash.com diikuti dengan tindakan sanksi kepada Zuckerberg dengan ancaman akan memecatnya dari kampus (walaupun ancaman ini tidak jadi

\footnotetext{
${ }^{11}$ Alo Liliweri, Komunikasi Antar Personal.h. 285-286

${ }^{12}$ Alo Liliweri, Komunikasi Antar Personal.h. 286-288
} 
direalisasikan). Atas tindakannya itu, Zuckerberg membela diri. Seperti yang dikutip dalam Maggot s Blog, Zuckerberg menyatakan bahwa:

"Tindakan pihak kampus yang memblokir situs facemash.com memang benar alasannya, namun sayang mereka tidak menyadari potensinya yang bisa saja menjadi alat pendongkrak popularitas bagi kampus itu sendiri. Cepat atau lambat, nanti juga akan ada orang lain yang membuat situs serupa."13

Facebook adalah situs web jaringan sosial yang diluncurkan pada 4 Februari 2004 dan didirikan oleh Mark Zuckerberg, seorang lulusan Harvard dan mantan murid Ardsley High School. Keanggotaannya pada awalnya dibatasi untuk siswa dari Harvard College. Dalam dua bulan selanjutnya, keanggotaannya diperluas ke sekolah lain di wilayah Boston (Boston College, Boston University, MIT, Tufts), Rochester, Stanford, NYU, Northwestern, dan semua sekolah yang termasuk dalam Ivy League. Banyak perguruan tinggi lain yang selanjutnya ditambahkan berturut-turut dalam kurun waktu satu tahun setelah peluncurannya.

Akhirnya, orang-orang yang memiliki alamat e-mail suatu universitas (seperti: .edu, .ac, uk, dll) dari seluruh dunia dapat juga bergabung dengan situs ini.

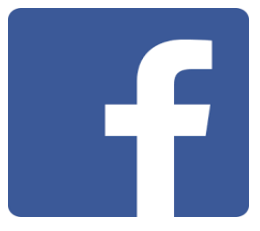

Gambar 1: Logo facebook

\section{Sumber: https://id.wikipedia.org/wiki/Facebook}

Untuk menjadi anggota facebook, maka langkah-langkah yang dapat dilakukan adalah sebagai berikut:

1. Buka situs Facebook di http://www.facebook.com

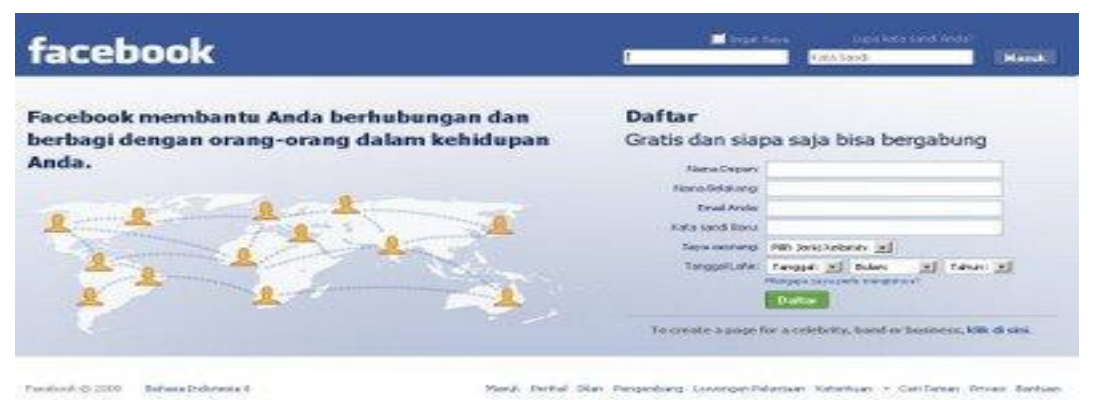

Gambar 2 : Halaman daftar / masuk akun facebook

Sumber : https://id.wikipedia.org/wiki/Facebook

2. Ubah bahasa menjadi Bahasa Indonesia untuk memudahkan pemahaman. Klik bahasa pada bagian kiri bawah. Pilih Bahasa Indonesia.

3. Isi data dengan lengkap pada kolom daftar isian. Klik tombol Mendaftar. Kemudian akan muncul halaman Pemeriksaan Keamanan. Isi kode keamanan yang diberikan, dipisahkan dengan spasi, jika tulisan susah dibaca klik "Coba kata yang lain" atau "pilih captcha suara". Klik Mendaftar sekali lagi.

\footnotetext{
${ }^{13}$ http://idid.facebook.com/pages/MyFacebookersmania/276271807947?v=app2347471856/akses pukul 16.55/17 Januari 2016
} 


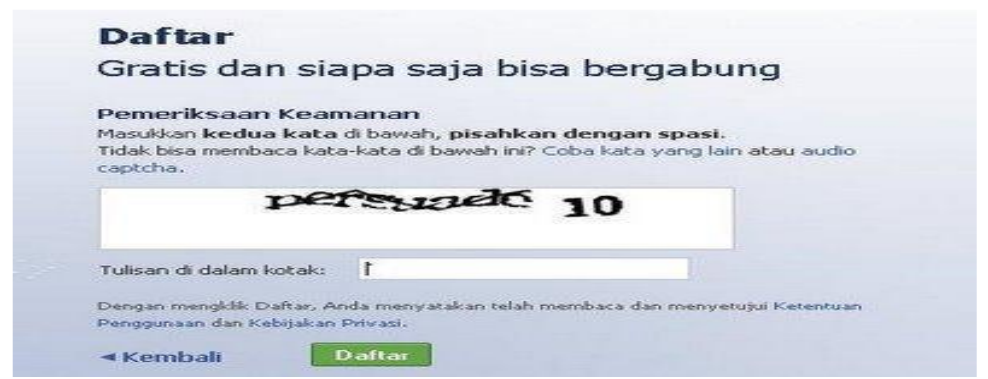

Gambar 3 : Halaman konfirmasi kode keamanan

Sumber : https://id.wikipedia.org/wiki/Facebook

4. Muncul halaman baru berupa Langkah 1, Langkah 2 dan Langkah 3. Isi password email pada Langkah 1 untuk mencari daftar teman dalam Email yang sudah mendaftar facebook. Langkah 2 isikan data sekolah dan perusahaan jika sudah bekerja atau lewati untuk menuju Langkah 3. Pada Langkah 3 upload foto dari computer atau bisa juga menggunakan webcam jika ada, simpan dan lanjutkan atau bisa lewati untuk langsung menuju halaman utama facebook.

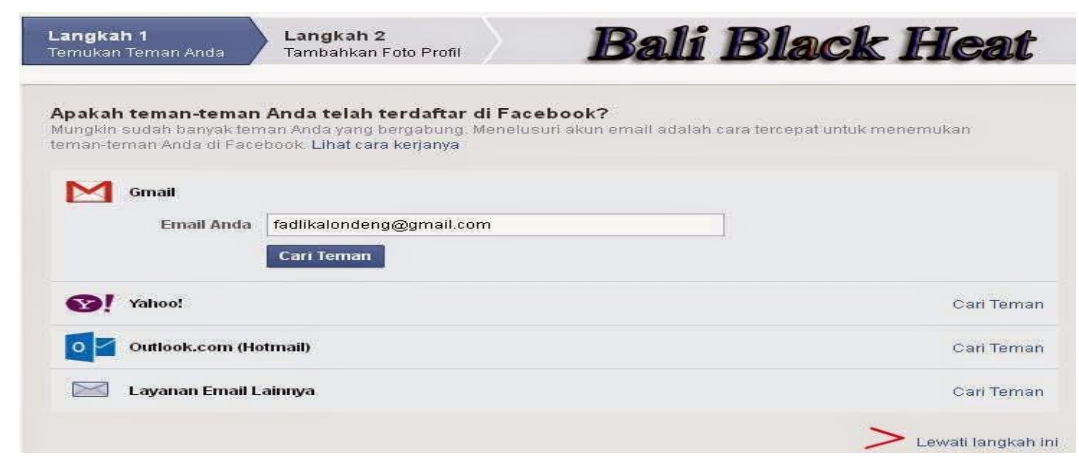

Gambar 4: halaman konfirmasi pertemanan

Sumber : https://id.wikipedia.org/wiki/Facebook

5. Periksa email yang digunakan pada saat mendaftar. Klik tautan (link) yang di kirim Facebook. Tautan ini digunakan untuk verifikasi email yang didaftarkan valid atau tidak.

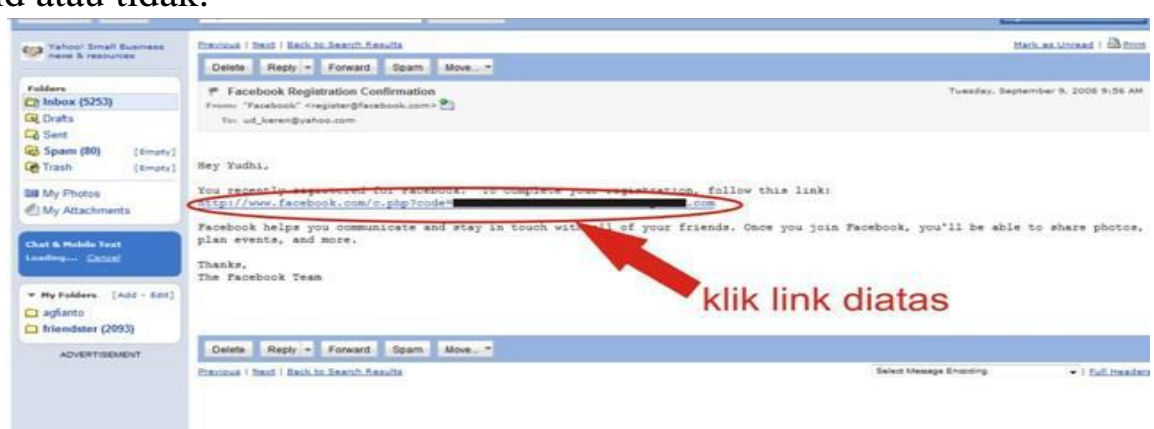

Gambar 5 : Halaman konfirmasi di Email Sumber : https://id.wikipedia.org/wiki/Facebook 
6. Login menggunakan email dan password.

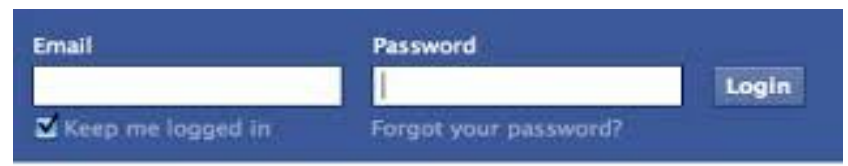

\section{In Up \\ free, and always will be. \\ Gambar 6: Login Facebook \\ Sumber : https://id.wikipedia.org/wiki/Facebook}

7. Setelah masuk halaman utama dan email sudah terverifikasi tambahkan koleksi foto dan isi profile secara lengkap untuk memudahkan pencarian oleh teman.

8. Atur privasi agar siapa saja yang bisa melihat profil di menu Akun / Pengaturan Privasi.

Facebook terdapat aplikasi-aplikasi yang dapat dimanfaatkan untuk membantu atau mempermudah pencarian data, setiap situs jejaring sosial memiliki aplikasi yang berbeda-beda begitupun dengan Facebook, aplikasi facebook dirancang supaya berbeda dengan jejaring sosial yang lain, aplikasi facebook antara lain:

\section{Foto (Photo)}

Foto dapat diaplikasikan dengan cara mengunggah foto sebanyak mungkin sebagai data pribadi atau publik, jika memiliki foto anggota facebook lain, maka dapat menandai foto tersebut dengan kata kunci (tag) berupa nama anggota tersebut, setelah memberikan kata kunci, foto tersebut akan muncul di album foto orang yang menandainya maupun profil teman yang ditandai. Pada tahun-tahun pertama, pengguna facebook dibatasi untuk mengunggah foto, yaitu 60 foto dalam satu album, pada tahun berikutnya yaitu bulan Mei 2009, pengguna facebook dapat mengunggah 200 foto dalam satu album. ${ }^{14}$

\section{Video}

Aplikasi video merupakan aplikasi yang menyerupai YouTube, anggota facebook dapat mengunggah video dalam semua format, dengan mensyaratkan ukuran file video dibawah $100 \mathrm{MB}$, tidak lebih dari 20 menit facebook akan mengubah file video tersebut dalam format flash (Flv).

\section{Grup (Group)}

Aplikasi grup merupakan aplikasi yang menggabungkan seseorang dengan kelompok lain yang memiliki tujuan yang sama, seseorang juga dapat membuat kelompok sendiri, grup digunakan untuk diskusi, pengumuman kegiatan, dan sebagainya. Grup biasanya digunakan oleh klub, perusahaan, dan organisasi masyarakat yang melibatkan massa, misalnya masyarakat umum, karyawan, anggota, pengguna layanan, pemegang saham atau pelanggan, sehingga facebook dapat menjebatani organisasi, kelompok, dan perusahaan tersebut untuk saling mengkoordinir atau berkomunikasi.

\section{Acara (Event)}

Aplikasi acara atau menu acara merupakan aplikasi yang dapat digunakan untuk mengundang anggota lain dalam acara yang akan digelar, dalam aplikasi ini yang perlu

\footnotetext{
${ }^{14} \mathrm{http} /$ /wikipedia.com diunduh pada tanggal 18/Januari/2016 pukul: 10.28 wib
} 
diperhatikan adalah mengisi nama acara, kata kunci, kota serta daftar tamu yang diundang, karena mengingat sifat acara tersebut baik formal, semi formal, atau untuk grup tertentu.

\section{Pasar (Marketplace)}

Pasar (marketplace) adalah aplikasi jual beli online sejenis e-bay dan Craigslist, fitur ini memungkinkan anggoata terhubung dengan orang lain yang akan membeli atau menjual barang, semua transaksi terjadi secara langsung antara seseorang atau anggota. Aplikasi ini diperkenalkan pada 14 Mei 2007 dengan kategori; dijual, perumahan, lowongan pekerjaan, dan lain-lain, saat penawaran bisa menyertakan bentuk barang yang tersedia maupun yang dicari, aplikasi pasar tersebut dapat dimanfaatkan oleh semua anggota facebook dan gratis (tidak dipungut biaya).

6. Kiriman (Post)

Aplikasi kiriman dapat dimanfaatkan untuk mengirim video, lagu, gambar, dan juga hal-hal lain yang ada dihalaman situs lain, ke halaman profil yang dikirim, apabila mengrim pesan maka dapat membalas atau comment, apabila mengirim gambar maka dapat mengunjungi situs tersebut dengan mengklik 'gambar tautan'.

7. Catatan (Note)

Aplikasi Facebook Note, tidak berbeda jauh dengan buku harian, pengguna facebook dapat membuat tulisan, gambar, foto, atau file lain dihalaman ini, sehingga catatan yang telah ditulis atau di update dapat dibaca oleh teman-teman di facebook. aplikasi tersebut diperkenalkan pada 22 Agustus 2006.

8. Hadiah (Gift)

Aplikasi ini, diterbitkan pada 8 Februari 2007, hadiah yang diberikan secara publik (public) akan muncul di dinding penerima beserta pesannya, jika hadiah diberikan secra pribdi (private), nama pengirim dan pesannya tidak dapat dibaca pengguna lain, semua hadiah (termasuk hadiah pribadi) yang diterima akan ditampilkan di kotak hadiah (terletak disebelah kanan atas dinding profil). Hadiah akan ditandai dengan nama depan pengirim (untuk hadiah publik) atau kata pribadi, facebooker juga bisa mengirim hadiah tanpa nama (Anonymous), tetapi anggota facebook yang bisa melihat profil penerima hadiah, bisa melihat hadiahnya, tetapi facebooker penerima hadiah saja yang bisa melihat pesannya. ${ }^{15}$

\section{METODOLOGI PENELITIAN}

Penelitian ini bersifat deskriptif kualitatif yakni menganalisis dan menggambarkan tentang realitas proses dakwah di media sosial. Lokasi penelitian ini adalah media sosial terkhusus facebook dengan objek penelitian yang akan diteliti meliputi aspek-aspek dakwah di media sosial yang terdiri dari dai dan bentuk dakwah. Pendekatan penelitian ini adalah studi fenomenologi dalam arti peneliti menghimpun data berkenaan dengan konsep, pendapat, pendirian, sikap, penilaian dan pemberian makna terhadap situasi atau pengalaman dalam kehidupan. Sumber data dalam penelitian ini adalah dai, facebooker dan aktif berdakwah di facebook sebagai sumber data primer yang diperoleh dengan cara observasi, wawancara, dan dokumentasi. Sedangkan data sekunder adalah data yang diperoleh dari berbagai literatur seperti buku, majalah, karya ilmiah yang relevan dengan penelitian. Instrumen utama dalam penelitian ini adalah peneliti sendiri dan jenis instrumen lain yang mencakup pedoman wawancara, pedoman observasi, dan alat dokumentasi.

\footnotetext{
${ }^{15}$ Rezky Muhammad, “Facebook VS Friendster”, CONNEXI, Yogyakarta, 2009, hlm:16
} 
Teknik analisis data dalam penelitian ini adalah model interaktif Miles dan Huberman yakni analisis data dilakukan saat pengumpulan data berlangsung, dan setelah pengumpulan data dalam periode tertentu, ${ }^{16}$ sebagai berikut: a) Reduksi Data yaitu merangkum dan memilih hal-hal yang pokok dan menfokuskan pada hal-hal yang penting dan mencari tema yang dianggap penting dan relevan dengan strategi dakwah di media sosial. b) Display atau Penyajian Data adalah bentuk uraian singkat, bagan, dan sejenisnya yang merupakan lanjutan setelah data direduksi dan melalui penyajian data tersebut, maka data terorganisasikan, tersusun dalam pola hubungan, sehingga akan semakin mudah dipahami; dan c) Verifikasi atau kesimpulan adalah penarikan kesimpulan yakni setelah data dipolakan, difokuskan dan disusun secara sistematik dalam bentuk naratif, maka melalui motode induksi, data tersebut disimpulkan. Sehingga makna data dapat ditemukan dalam bentuk tafsiran dan argumentasi. Kesimpulan juga diverifikasi selama penelitian berlangsung. Kesimpulan yang diambil sekiranya masih terdapat kekurangan akan ditambahkan.

\section{HASIL PENELITIAN DAN PEMBAHASAN}

Dalam kehidupan bermasyarakat, seringkali dakwah diartikan hanya ulama sebagai pendakwah menyampaikan pesannya di hadapan khalayak. Akhirnya dakwah dipahami sebagai tugas ulama semata, bentuk dakwah hanya ceramah, dan mitra dakwah selalu terdiri dari banyak orang. Pemahaman yang tidak tepat ini telah diterima secara umum oleh masyarakat, sehingga perlu dikemukakan beberapa fenomena dakwah yang lain. ${ }^{17}$

Dakwah bukan hanya kewenangan ulama atau tokoh agama. Setiap muslim bisa melakukan dakwah, karena dakwah bukan hanya ceramah agama. Pernah seorang dai melakukan tugas dakwah di London, dai tersebut ditemani makan sahur oleh Muntako, seorang pekerja dari semarang yang sudah lima tahun di Inggris. Ia kurus kering, berpuasa dengan khusyuk sekalipun bekerja siang dan malam di tengah-tengah masyarakat London yang terkenal gila bola. Siang hari dengan bibirnya yang kering, ia berangkat bekerja dan baru pulang menjelang akhir waktu sahur. Ia bekerja sedemikian berat, karena ia ingin memberi kehidupan yang layak untuk keluarganya di tanah air, khususnya untuk masa depan pendidikan anak satu-satunya yang ia sebut sebagai titipan mulia Ilahi. Ia bersedia hidup ekonomis di tengah masyarakat yang hidup mewah dan konsumtif, karena ia berkeinginan membantu orang-orang tua, para janda, dan anakanak usia sekolah yang terlantar di kampung halamannya. Ia telah membeli sebidang tanah yang dipersiapkan untuk panti asuhan yatim dan fakir miskin kelak ketika ia kembali ke tanah air. Ia yakin bahwa Allah akan membantunya. Ia dengan mantap mengatakan Allah maha kaya. Dalam standar kehidupan pada umumnya, pekerja di restoran tersebut sebenarnya termasuk mereka yang tak berdaya. Ia harus ke luar negeri karena keterbatasan lapangan kerja di Indonesia. Akan tetapi, ia tetap bertekad melakukan pemberdayaan kepada orang lain. Belum pernah ada orang menyebut Muntako sebagai pendakwah, karena ia tidak berceramah, padahal upaya Muntako yang terpuji itu dapat melebihi penceramah. Muntako adalah pendakwah, Ia melakukan dakwah pemberdayaan masyarakat. ${ }^{18}$

\footnotetext{
${ }^{16}$ Sugiono, Metode Penelitian Kuantitatif, kualitatif dan R\&D, h.246

${ }^{17}$ Moh. Ali Aziz, Ilmu Dakwah, (cet III Ed. Revisi, Jakarta: Kencana, 2004). h. 2

${ }^{18}$ Moh. Ali Aziz, Ilmu Dakwah Edisi Revisi, h. 2-3
} 
Fenomena yang lain, Yudo pria berambut panjang dan bertato, Ia fanatik dengan agama Islam yang dianutnya, namun tidak pernah ke masjid. Seminggu sekali ia mengumpulkan pemuda dan orang dewasa yang sesamanya pecinta lagu dangdut dan sama-sama tidak pernah ke masjid, beberapa di antaranya bukan muslim. Mereka akrab dan riang dalam setiap berlatih musik dangdut. Suatu saat yudo minta izin ketua RT untuk menggunakan pos kamling untuk bakar-bakar ikan bersama menyambut malam lailatul qadar 27 Ramadhan. Tidak ada yang tahu pesan apa yang disampaikan Yudo kepada kelompoknya pada malam itu. Tapi selesai Shalat Tarawih pak RT menyampaikan bahwa ada dua orang masuk Islam di depan Yudo. Bahkan, beberapa orang bertato lainnya kemudian sesekali pergi ke masjid bersamanya. Yudo adalah pendakwah tanpa mimbar. Ia melakukan dakwah "ikan bakar" yang menyentuh hati kepada mereka yang bertahun-tahun tidak tersentuh oleh dakwah dalam bentuk ceramah. $^{19}$

Ada juga pendakwah yang menfokuskan dakwahnya untuk menyelamatkan iman generasi muslim yaitu dilakukan oleh 35 pelajar muslim Indonesia yang tergabung dalam Keluarga Besar Britania Raya (KIBAR). Mereka menulis dua jilid buku tebal yang berjudul paket Permainan Interaktif Pendidikan Aqidah untuk anak TK. Buku ini menjadi pegangan guru Islam yang mengajar keimanan untuk anak-anak diplomat, pelajar ataupun pekerja di Inggris. Hal ini dilatarbelakangi oleh kesulitan dalam pengajaran agama bagi anak-anak muslim di Sheffield dan Inggris pada umumnya. Anak-anak dibiasakan untuk bersikap kritis termasuk dalam masalah agama, sehingga model pendidikan agama di Indonesia tidak bisa diterapkan sama sekali. Usaha KIBAR tersebut dapat dikatakan sebagai kegiatan dakwah dengan tulisan. Siapapun bisa menjadi pendakwah dengan menulis pesan Islam di majalah, koran, atau Internet. ${ }^{20}$

Beberapa fenomena di atas, dakwah Islam meliputi wilayah yang luas dalam semua aspek kehidupan. Ia memiliki ragam bentuk, metode, media, pesan, pelaku, dan mitra dakwah. Umat Islam tidak bisa terlepas dari kegiatan dakwah, baik itu sebagai pendakwah ataupun sebagai mitra dakwah. Dakwah adalah denyut nadi Islam. Islam dapat bergerak dan hidup karen dakwah. Luasnya wilayah dakwah dan peranannya yang besar dalam Islam membuat kadang merasa kesulitan dalam merumuskan defenisi dakwah secara tepat. ${ }^{21}$ Dengan perkembangan zaman hari ini maka fenomena dakwah juga mengalami perkembang. Begitu banyak media bermunculan yang bisa digunakan sebagai media dakwah.

Teknologi adalah salah satu media yang bisa digunakan dalam berdakwah. Dalam Kamus Besar Bahasa Indonesia, teknologi diartikan sebagai "kemampuan teknik yang berlandaskan pengetahuan ilmu eksakta dan berdasarkan proses teknis". Menelusuri pandangan Al-Qur'an tentang teknologi, maka banyak sekali ayat AlQur'an yang berbicara tentang materi dan fenomena tentang alam raya terdapat sekitar 750 ayat Al-Qur'an. ${ }^{22}$ Dan juga memerintahkan manusia untuk mengetahui dan memanfaatkan alam ini, secara tegas dan berulang-ulang Al- Qur'an menyatakan bahwa alam raya diciptakan dan ditundukkan Allah untuk manusia.

\footnotetext{
${ }^{19}$ Moh. Ali Aziz, Ilmu Dakwah Edisi Revisi, h. 3

${ }^{20}$ Moh. Ali Aziz, Ilmu Dakwah Edisi Revisi, h. 4

${ }^{21}$ Moh. Ali Aziz, Ilmu Dakwah Edisi Revisi, h. 5

${ }^{22}$ M Quraish Syihab, Wawasan Al-Qur'an (Tafsir Maudhu'i Atas Pelbagai Persoalan Umat, (PT Mizan Pustaka Anggota IKAPI, Bandung, cet:19 2007). h.441
} 
Facebook yang lahir tahun 2004 namun penggunaan jejaring sosial di internet ini baru meningkat pesat di Indonesia pada tahun 2008 meninggalkan situs jejaring yang populer sebelumnya yaitu friendster.com. Peningkatan pesat pengguna facebook di Indonesia salah satunya dipicu mudahnya penggunaan akses facebook menggunakan telepon selular. Terutama yang sudah meletakkan fitur facebook sebagai fitur standar atau favorit dari beberapa merek telepon selular di antaranya peningkatan pesat penggunaan merek blackberry dan sekarang beralih ke android. Pada 2009 fitur facebook bahkan menjadi nilai jual tersendiri bagi para produsen telepon selular yang menjual produknya di Indonesia. Pada perkembangannya para pengguna internet pemula mengakses facebook lebih awal sebelum menggunakan fitur internet lainnya. Hingga sekarang pengguna jejaring sosial facebook di Indonesia mencapai 69 juta orang. Indonesia menjadi negara dengan pengguna facebook terbesar keempat di dunia. $^{23}$

Facebook dalam perkembangannya menjadi wadah pola komunikasi masyarakat modern dengan gaya hidup individualis yang intensitas komunikasi personal secara langsung sangatlah minim. Kebutuhan manusia untuk berkomunikasi tidak bisa ditawar lagi, karena komunikasi itu penting untuk membangun konsep diri, aktualisasi diri, kelangsungan hidup, kebahagiaan, terhindar dari tekanan dan ketegangan dan memupuk hubungan dengan orang lain. ${ }^{24}$

Facebook juga mampu menghadirkan budaya baru di Indonesia di era teknologi sekarang ini. Dalam pengertian bahwa budaya barat masuk ke Indonesia. Hal ini pernah diungkap oleh Herbert Schiller pada tahun 1973 dalam teori imperialisme budaya. Teori imperialisme budaya menyatakan bahwa negara Barat mendominasi media di seluruh dunia ini. Ini berarti pula, media massa negara Barat juga mendominasi media massa di dunia ketiga. Alasannya, media Barat mempunyai efek yang kuat untuk mempengaruhi media dunia ketiga. Media Barat sangat mengesankan bagi media di dunia ketiga. Sehingga mereka ingin meniru budaya yang muncul lewat media tersebut. Dalam perspektif teori ini, ketika terjadi proses peniruan media negara berkembang dari negara maju, saat itulah terjadi penghancuran budaya asli di negara ketiga.

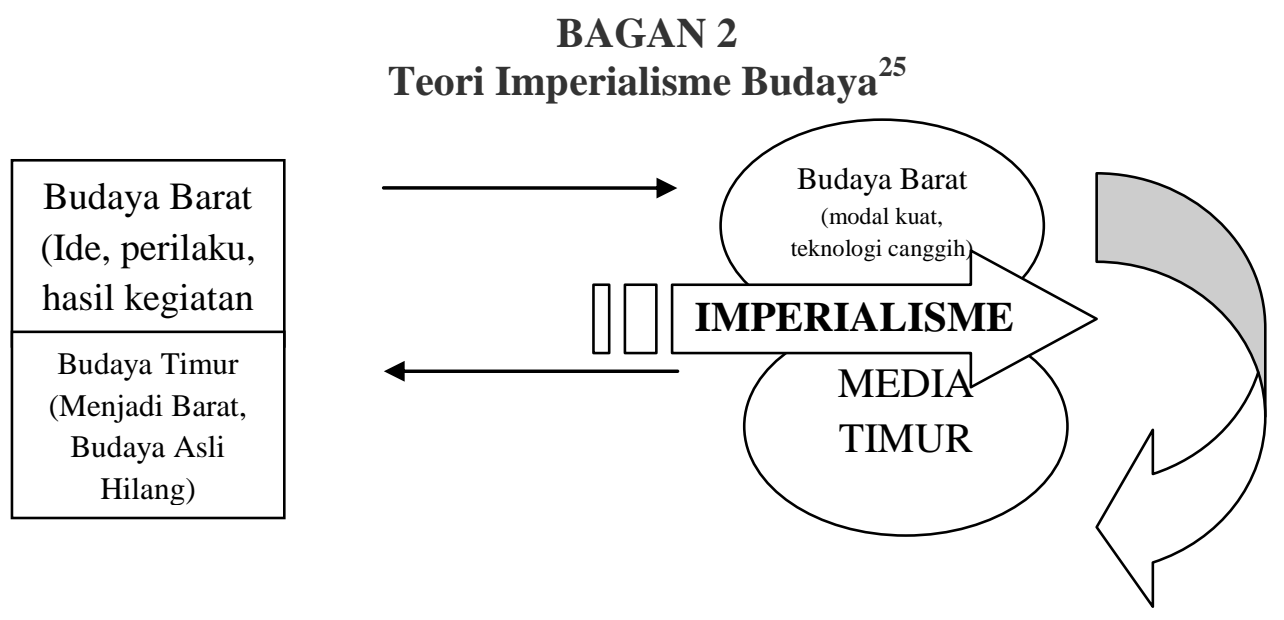

\footnotetext{
${ }^{23}$ http://techno.okezone.com/read/2014/09/22/55/1042737/indonesia-engguna-facebookkeempat-terbesar-di-dunia, di akses 23 januari 2016

${ }^{24}$ Deddy Mulyana, Ilmu Komunikasi, (Bandung: Rosdakarya, 2005), hal. 5.

${ }^{25}$ Nurudin, Pengantar Komunikasi Massa, (Rajawali Pers, Jakarta, 2007)), h. 178
} 
Terdapat dua alasan mengapa media massa barat mampu mendominasi media massa dunia: Pertama dunia barat mempunyai uang/ modal. Dengan uang, mereka akan bisa berbut apa saja untuk memproduksi berbagai ragam sajian yang dibutuhkan media massa. Bahkan media Barat sudah dikembangkan secara kapitalis. Media massa barat sudah dikembangkan menjadi industri yang juga mementingkan keuntungan. Kedua, dunia Barat mempunyai kemapanan atas teknologi. Dengan teknologi modern yang mereka punya memungkinkan sajian media massa diproduksi secara lebih baik, meyakinkan dan seolah terlihat nyata.

Teori ini juga menerangkan bahwa ada satu kebenaran yang diyakininya. Sepanjang negara dunia ketiga terus menerus menyiarkan atau mengisi media massanya berasal dari negara Barat, orang-orang dunia ketiga akan selalu percaya apa yang seharusnya mereka kerjakan, pikir dan rasakan. Perilaku ini sama persis seperti yang dilakukan oleh orang-orang yang berasal dari kebudayaan Barat. Teori imperislisme budaya ini juga tak lepas dari kritikan. Teori ini terlalu memandang sebelah mata kekuatan audience di dalam menerima terpaan media massa dan menginterpretasikan pesan-pesannya. Ini artinya, teori ini menganggap bahwa budaya yang berbeda (yang tentunya lebih maju) akan selalu membawa pengaruh peniruan pada orang-orang yang berbeda budaya. ${ }^{26}$

Dahsyatnya situs jejaring sosial ini merebak di kalangan masyarakat adalah akibat dari tingginya rasa eksistensi diri tetapi tidak diiringi oleh terpenuhinya sarana eksistensi diri yang memadahi, eksistensi dalam artian kebutuhan akan aktualisasi diri. Dalam ilmu psikologi, kebutuhan aktualisasi diri menurut teori hirarki kebutuhan Maslow adalah menempati urutan tertinggi dari lima kebutuhan dasar manusia. Menurut Abraham Maslow yang ditulis oleh Alex Sobar, mengatakan bahwa kebutuhan dasar manusia itu terdiri atas kebutuhan fisiologis, rasa aman, cinta, penghargaan dan aktualisasi diri. ${ }^{27}$ Dari sindrom tersebut, terjadi trend baru yang menggabungkan antara dakwah dengan facebook yaitu dakwah via facebook. Dakwah via facebook merupakan cara yang cukup efektif, mengingat tempatnya yang bisa dilakukan di mana saja dan waktunya bisa di lakukan kapan saja disamping itu dengan biaya yang relatif murah, hanya membayar untuk akses internet.

Fenomena dakwah melalui jejaring sosial facebook khususnya di Indonesia mengalami perkembangan yang cukup pesat. Hal ini ditandai dengan hadirnya para aktivis dakwah untuk memanfaatkan facebook sebagai sarana media dakwah islam. Di mana semua pengguna facebook bisa melihat, belajar di facebook untuk menambah wawasan keilmuan dan informasi seputar dunia islam. Pemanfaatan facebook sebagai media dakwah ini yang akan menjembatani kemajuan teknologi dengan proses dakwah, supaya masyarakat lebih mengenal syari'at dan tidak berargumen bahwa dakwah hanya dalam pengajian. Sebab eksistansi dari dakwah adalah menyeru kepada yang ma'ruf dan mencegah kepada hal yang munkar. ${ }^{28}$

Halaman facebook mudah diakses untuk update status, sehingga mempermudah untuk melakukan syiar lebih luas, berbagai fiturpun telah tambahan seperti dapat mencari teman yang telah lama tidak bertemu, hal ini dapat menjalin silaturrahim

\footnotetext{
${ }^{26}$ Nurudin, Pengantar Komunikasi Massa, h. 176

${ }^{27}$ Alex Sobur, Psikologi Umum, (Bandung: Pustaka Setia, 2003), hal. 273

28 Hasil wawancara dengan Abdul Rahman Rahim (aktivis dakwah di facebook sekaligus pengasuh pondok pesantren Darul Istiqomah Maccopa Maros) pada tanggal 20 januari 2016
} 
kembali, begitu pun dengan fitur yang lain dapat dimanfaatkan sebagaimana mestinya dengan tujuan amar ma'ruf nahi munkar.

Dengan adanya jejaring ini maka dai diharapkan dapat memanfaatkan media ini dengan baik untuk tetap mengamalkan amar ma'ruf nahi munkar melalui berbagai media. Hingga saat ini aktivitas dakwah di kalangan umat muslim masih tetap berlangsung dan perhatian pada dakwah semakin besar. Dakwah tidak lagi dilakukan sebatas pemberian khutbah di masjid/mushalla, kantor-kantor, sekolah dan lembaga formal lainnya. Seiring dengan meningkatnya kemajuan teknologi informasi penyebaran dakwah Islam tersebar melalui media teknologi, khususnya teknologi informasi seperti internet. Dengan trend digital life, sesungguhnya kemudahan dari Allah SWT untuk nasyul fikrah semakin terbuka lebar. Dakwah melalui internet merupakan suatu inovasi terbaru dalam syair Islam, dan tentunya akan memudahkan para dai dalam melebarkan sayap-sayap dakwahnya. Penggunaan media internet sebagai media dakwah merupakan kesempatan dan tantangan untuk mengembangkan dan memperluas cakrawala dakwah Islam. Kesempatan yang dimaksud ialah bagaimana orang-orang yang peduli terhadap kemampuan dakwah maupun memanfaatkan media internet tersebut sebagai sarana dan media dakwah untuk menunjang proses dakwah Islamiyah. ${ }^{29}$

Facebook seolah menjadikan jarak, waktu dan ruang bukan lagi masalah untuk saling bertegur sapa bahkan untuk memperluas pertemanan pun kini semakin mudah melalui facebook. Para pengguna facebook dapat saling menyapa dan menjalin hubungan pertemanan dengan siapa saja dari segala penjuru dunia tanpa harus tatap muka. Bahkan tak jarang kita dapat kembali saling berhubungan dengan seorang teman lama yang bahkan mungkin telah bertahun-tahun tidak bertatap muka. Melaui facebook kita juga dapat menanbahkan teman-teman baru dengan meng-add pengguna lain. Facebook tampaknya kini telah menjadi tempat untuk saling berkomunikasi dan bertukar informasi yang banyak digemari oleh para penggunanya untuk tetap ilmu dari halaman-halaman yang disukai oleh para pengguna. Seperti halnya dalam penyampaian dakwah sekalipun dapat dilakukan di mana kapan saja dan melalui media apa saja tak ketinggalan pula pemanfaatan facebook dalam kegiatan berdakwah. Dengan adanya facebook pula, para pengguna juga bisa mendapatkan berbagai macam ilmu dengan duduk di depan layar komputer, laptop, maupun handphone yang canggih. Hanya dengan menyukai atau melike halamam (page) yang disukai atau dihendaki info macam apa yang diperlukan.

Banyak pendakwah yang menggunakan facebook sebagai sarana berinteraksi dengan para pencari ilmu. Pembahasan tentang hadits, ayat-ayat Al-Qur'an tertentu, ataupun kisah-kisah inspiratif serta motivasi islam. Disebarkan melalui status facebook. Namun tak sedikit di antara mereka yang kadang tak mendapat respon dari para pengguna yang lain. Berbeda ketika yang membuat status dakwah tersebut adalah orang sudah terkenal seperti Yusuf Mansur, KH. Abdullah Gymnastiar, Ustadz Arifin Ilham, dan lain-lain. Meskipun dalil yang mereka gunakan sama, namun penjelasan atau penggambaran dengan konteks kekinian membuat respon dari facebooker berbeda. ${ }^{30}$

Fenomena seperti ini telah digambarkan dalam teori kredibiltas sumber. Teori ini menjelaskan bahwa seseorang dimungkinkan lebih mudah dibujuk (dipersuasi) jika sumber-sumber persuasinya memiliki kredibilitas yang cukup. Kredibilitas tidak hanya

\footnotetext{
${ }^{29}$ Hasil wawancara dengan Dzata Bahjah (aktivis dakwah di facebook sekaligus aktivis IMM) pada tanggal 23 januari 2016

30 Hasil wawancara dengan Ahmad Dahlan (aktivis dakwah di facebook sekaligus tenaga pengajar di pondok pesantren Darul Aman Makassar) pada tanggal 24 januari 2016
} 
terkait dengan orang, tetapi juga berhubungan dengan sumber-sumber yang lain, seperti jenis produk atau jenis kelembagaan tertentu.

Terdapat tiga model guna memahami ruang lingkup teori kredibilitas sumber ini, yakni;

a. Model faktor yang membantu menetapkan sejauh mana pihak penerima menilai kredibilitas suatu sumber.

b. Model fungsional yang memandang kredibilitas sebagai tingkat di mana sumber mampu memuaskan kebutuhan-kebutuhan individu penerima.

c. Model konstruktifis untuk menganalisis apa yang dilakukan penerima dengan adanya usulan-usulan sumber. ${ }^{31}$

Teori inilah yang diadopsi ke dalam praktik dakwah dengan nama " teori citra da'i". ${ }^{32}$ Kredibilitas seorang da'i tidak tumbuh dengan sendirinya, tetapi dicapai melalui usaha yang intens dan berkesinambungan. Alwi Shihab menyebutkan bahwa faktor keteladanan sangat penting untuk mencapai kesusksesan dalam berdakwah. Tidak mungkin mengajak orang lain untuk membangun karakter moral yang tinggi dan mencegah aktivitas yang tidak Islami jika da'i itu sendiri tidak Islam. ${ }^{33}$ Karenanya, seorang da'i perlu memiliki integritas dan berbagai kelengkapan pengetahuan yang dibutuhkan dalam melaksanakan dakwah.

\section{KESIMPULAN}

Fenomena yang sedang sangat digemari di era tahun 2000-an ini yaitu sebuah jejaring sosial facebook, dapat dikatakan sebagai sebuah revolusi cara berkomunikasi untuk mendapatkan teman. Dalam kehidupan normal sehari-hari selayaknya mendapatkan teman biasanya secara langsung tatap muka dan bisa akrab dengan teman juga secara tatap muka. Tetapi dengan jejaring sosial facebook, mendapatkan teman dan berbincang dengannya secara leluasa hanya sekali klik, maka semua deskripsi tentang teman baru bisa didapatkan.

\footnotetext{
${ }^{31}$ Usman, "Mencegah Radikalisme Agama (Dakwah Komunikatif Muhammadiyah Di Sulawesi Selatan)”, Disertasi, Jakarta: Sekolah Pascasarjana (UIN) Syarif Hidayatullah, 2010. H. 51

${ }^{32}$ Teori ini menjelaskan bahwa kualitas dan kepribadian seorang da'i sangat menentukan tingkat keberhasilan dakwah. Kualitas yang dimiliki oleh seorang da'i mempengaruhi citranya di hadapan mad'u. Asumsi dasar teori ini adalah citra atau kredibilitas seorang da'i sangat menentukan penerimaan mad'u terhadap pesan-pesan dakwah yang disampaikannya. Semakin tinggi kredibilitas da'i, maka semakin tinggi pula tingkat penerimaan mad'u terhadap pesan-pesan dakwah yang disampaikannya. Seorang da'i yang berkredibilitas tinggi adalah seorang yang mempunyai kompetensi di bidangnya, memiliki integritas kepribadian dan ketulusan jiwa. Ketika kredibilitas ini dimiliki oleh seorang dai'i, maka dia akan memiliki citra positif di hadapan mad'u.

33 Alwi Shihab, Islam Inklusif: Menuju Sikap Terbuka Dalam Beragama, ( Bandung: Mizan, 1999), h.254
} 


\section{DAFTAR PUSTAKA}

Aziz, Moh. Ali, Ilmu Dakwah, Edisi Revisi, Jakarta: Kencana, 2012.

Hidayatullah, Syarif, Islam Virtual (keberadaan Dunia Islam di Internet) . Cet I Jakarta; Penerbit Mifta. 2003.

Ishadi, SK., Prospek Bisnis Informasi di Indonesia. Cet. I Bandung; Pustaka Pelopor. 1999.

Jasad, Usman, Dakwah \& Kamunikasi Transformatif, makassar: Alauddin press, 2011

Liliweri, Alo, Komunikasi Antar Personal: Jakarta: Kencana, 2015

Muhammad, Rezky, “Facebook VS Friendster”, CONNEXI, Yogyakarta, 2009

Mulyana, Deddy, Ilmu Komunikasi, Bandung: Rosdakarya, 2005

Nurudin, Pengantar Komunikasi Massa, Rajawali Pers, Jakarta, 2007.

PP. Muhammadiyah, Dakwah kultural Muhammadiyah, Cet II; Yogyakarta: PT. Surya Sarana Utama, 2005

Shihab, Alwi, Islam Inklusif: Menuju Sikap Terbuka Dalam Beragama, Bandung: Mizan, 1999.

Shihab, M Quraish, Wawasan Al-Qur'an (Tafsir Maudhu'i Atas Pelbagai Persoalan Umat)”, PT Mizan Pustaka Anggota IKAPI, Bandung, cet:19 2007

Sobur, Alex, Psikologi Umum, Bandung: Pustaka Setia, 2003

Sugiono, Metode Penelitian Kuantitatif, kualitatif dan R\&D, Bandung: Alfabet, 2009.

Usman, "Mencegah Radikalisme Agama (Dakwah Komunikatif Muhammadiyah Di Sulawesi Selatan)", Disertasi, Jakarta: Sekolah Pascasarjana (UIN) Syarif Hidayatullah

http://idid.facebook.com/pages/MyFacebookersmania/276271807947?v=app234747185 6/aksespukul 16.55/17 Januari 2016

http//wikipedia.com diunduh pada tanggal 18/Januari/2016 pukul: 10.28 wib http://techno.okezone.com/read/2014/09/22/55/1042737/indonesia-engguna-facebookkeempat-terbesar-di-dunia, di akses 23 januari 2016

http://neysya-jatidiri.blogspot.com/2012/06/facebook-sebagai-media-dakwah.html di akses pada 1 maret 2015 jam 12.50 wib 